Rarely certain other conditions may be confused with the common nappy rashes. A recent review ${ }^{1}$ listed 23 conditions to consider in the differential diagnosis. According to Burgoon et $a l^{4}$ the diseases most frequently mistaken for a persistent or resistant nappy rash are Letterer-Siwe disease (in which there may be proliferative or erosive lesions and purpuric papules in the nappy area); acrodermatitis enteropathica (perineal and perioral dermatitis, with diarrhoea and wasting); and congenital syphilis. Another chronic eruption in the nappy area is granuloma gluteale infantum, ${ }^{7}$ characterised by reddish blue nodules resembling foreign body granulomata.

The most important line of treatment is convincing the mother of the importance of changing wet nappies as frequently as reasonably possible. Unfortunately, in some homes this cannot be achieved. Sometimes the mother's supply of nappies is insufficient because of their expense; perhaps financial help can be arranged. After a wet nappy has been removed the skin should be washed with water (some say without the use of soap) and dried thoroughly, exposing it to the air if possible and applying talc. Nappies should be thoroughly rinsed so that they contain no residue of soap or detergent. A polypropylene one-way nappy (Snugglers, Marathon, etc) is useful for the night: the synthetic fibre does not absorb moisture so that the urine passes through to the outer towelling nappy. Airtight occlusive plastic or rubber pants inhibit the evaporation of water from the skin and should not be used.

There is no one application for the common mild nappy rash. A simple emollient, a quarternary ammonium preparation, or a silicon barrier cream may be all that is required. For more severe rashes, clioquinol and hydrocortisone ointment $B P C$ is satisfactory. A $1 \%$ hydrocortisone cream given for up to one week may be effective and will not harm the skin, but topical fluorinated corticosteroid applications are unnecessary and dangerous. Their absorption may be enhanced by the condition of the skin, the skin may be further damaged, and general features of corticosteroid overdosage may result. Giving medicine by mouth with the aim of changing the $\mathrm{pH}$ of the urine is futile. Boric acid or mercury applications should never be used because of the dangers of systemic absorption.

When any nappy rash, whatever its nature, fails to respond to these simple measures, or when there are isolated spots, a candida infection should be assumed to be present-and the clinical features of thrush infection may be obvious. The specific treatment is with nystatin cream or ointment, or an ointment containing clioquinol, nystatin, and hydrocortisone, which is also effective for the seborrhoeic or psoriasiform varieties. Though resistance of candida to nystatin is said not to occur, very occasionally an infant may be seen with oral or perineal thrush apparently unresponsive to nystatin but cleared quickly by miconazole or amphotericin. An oral antifungal preparation, ketoconazole, ${ }^{8}$ has also been used successfully for candidiasis resistant to other treatment. Gentian violet, for mouth or perineum, has long since been discarded because of its annoying staining properties and its replacement by more effective antibiotics.

1 Weston WL, Lane AT, Weston JA. Diaper dermatitis: current concepts. Pediatrics $1980 ; 66$ :532-6.

${ }^{2}$ Leyden JJ, Katz S, Stewart R, Kligman AM. Urinary ammonia and ammonia-producing microorganisms in infants with and without diaper dermatitis. Arch Dermatol 1977;113:1678-80.

${ }^{3}$ Leyden JJ, Kligman AM. The role of microorganisms in diaper dermatitis. Arch Dermatol 1978;114:57-9.

${ }^{4}$ Burgoon CF, Urbach F, Grover WD. Diaper dermatitis. Pediatr Clin North Am 1961;8:835-56.

${ }^{5}$ Dixon PN, Warin RP, English MP. Alimentary Candida albicans and napkin rashes. Br $\mathcal{F}$ Dermatol 1972;86:458-62.
${ }^{6}$ Dixon PN, Warin RP, English MP. Role of Candida albicans infection in napkin rashes. $\mathrm{Br} \mathrm{Med} \mathcal{F} 1969$;ii:23-7.

' Simmons IJ. Granuloma gluteale infantum. Australian fournal of Dermatology 1977;18:20-4.

${ }^{8}$ Rosenblatt HM, Byrne W, Ament ME, Graybill J, Stiehm ER. Successful treatment of chronic mucocutaneous candidiasis with ketoconazole. $\mathcal{f}$ Pediatr 1980;97:657-60.

\section{Drug-induced bullous eruptions}

Blisters are a well-known manifestation of cutaneous reactions to drugs. Severe eczematous or urticarial drug eruptions may become bullous, and drugs such as nalidixic acid that cause photosensitivity may produce blisters. ${ }^{1}$ The recognised drug-induced syndromes of erythema multiforme, toxic epidermal necrolysis, and porphyria cutanea tarda are characteristically bullous. The fixed drug eruptions may also develop blisters. Another interesting cause of bullous lesions is drug-induced coma, ${ }^{2}$ when subepidermal bullae develop over areas of trauma. Overdose; with barbiturates, methadone, meprobamate, imipramine, nitrazepam, and glutethimide have each been implicated as causes of blisters in comatose patients.

During the past 10 years drug-induced bullous eruptions have been reported with increasing frequency. Frusemide produces the greatest variety of such eruptions-namely, erythema multiforme, ${ }^{3}$ a bullous haemorrhagic eruption, ${ }^{4}$ bullous pemphigoid, ${ }^{5}$ acquired epidermolysis bullosa, ${ }^{6}$ and a phototoxic bullous eruption. ${ }^{7}$ Azapropazone has produced a bizarre bullous eruption ${ }^{8}$; busulphan may cause a bullous lesion like erythema multiforme ${ }^{9}$; and methotrexate has produced epidermal necrolysis in a patient with psoriasis. ${ }^{10}$

Of great interest to the dermatologist and immunopathologist is the increasing number of reports over the past five years of drug-induced bullous eruptions that mimic the classical bullous dermatoses. Penicillamine is the most common offender, producing eruptions resembling pemphigus vulgaris $^{11} 12$ and foliaceus. ${ }^{13}$ Rifampicin ${ }^{14}$ may also produce pemphigus. Frusemide may give rise to bullous pemphigoid, ${ }^{5}$ as may psoralen and ultraviolet treatment for psoriasis. ${ }^{15}$

The most recent report of a drug-induced bullous eruption concerns an unusual case of anogenital cicatricial pemphigoid due to clonidine. ${ }^{16}$ This case, like other drug-induced bullous syndromes, shows the same immunopathological abnormalities that are seen in the classical bullous dermatoses. This important finding suggests that further study of drug-induced bullous eruptions may help us to elucidate the pathogenesis of this group of disorders. Local drug-induced metabolic disturbance (possibly in the cyclic AMP system) at the level of the basal cells might lead to the formation of immunogens and be one of the initiating factors in subepidermal bullous immune dermatoses. ${ }^{16}$ Clonidine is an alpha-adrenergicreceptor-stimulating agent; and recently a case of ocular cicatricial pemphigoid has been attributed to practolol, a beta-adrenergic-receptor-blocking agent. ${ }^{17}$ One hypothesis is that beta-blockers may interact with the cyclic-AMP system of epidermal cells, ${ }^{18}$ and possibly such a metabolic disruption could make the basal cells antigenic. Furthermore, there is evidence of basal cell cytoplasmic autoantibodies (BCC antibodies) in the sera of patients with drug-induced eruptions. ${ }^{1920}$ This suggests that some drugs or their breakdown products may have a strong affinity for the basal cell layer of 
human epidermis, and may form hapten-protein carrier complexes that can behave as immunogens. Alternatively, the basal cell antibodies might be formed in response to death and breakdown of basal cells as a result of the accumulation of the drug or its derivative.

Thus the deposition of immunoglobulin and complement in drug-induced bullous eruptions at sites identical with those in the classical bullous dermatoses should stimulate the investigator to a closer look for the initial site and cause of metabolic or immunological disturbance that leads to the formation of blisters. We may hope that the drug-induced mimicry will serve as an experimental model. Moreover, drug ingestion is an important triggering factor that must be considered by the clinical dermatologist faced with patients presenting with bullous eruptions, especially if these are atypical.

1 Birkett DA, Garretts M, Stevenson CJ. Phototoxic bullous eruptions due to nalidixic acid. Br $\mathcal{F}$ Dermatol $1969 ; 81$ :342-4.

2 Mandy S, Ackerman AB. Characteristic traumatic skin lesions in druginduced coma. F $A M A 1970 ; 213: 253-6$.

${ }^{3}$ Gibson TP, Blue P. Erythema multiforme and furosemide. $¥ A M A 1970$; 212:1709.

4 Ebringer A, Adam WR, Parkin JD. Bullous haemorrhagic eruption associated with frusemide. Med $\mathcal{F}$ Aust $1969 ; \mathrm{i}: 768-71$.

${ }^{5}$ Fellner MJ, Katz JM. Occurrence of bullous pemphigoid after frusemide therapy. Arch Dermatol 1976;112:75-7.

${ }^{6}$ Kennedy AC, Lyell A. Acquired epidermolysis bullosa due to high-dose frusemide. Br Med f 1976;i:1509-10.

7 Burry JN, Lawrence JR. Phototoxic blisters from high frusemide dosage. Brf Dermatol 1976;94:495-9.

${ }^{8}$ Barker DJ, Cotterill JA. Skin eruptions due to azapropazone. Lancet $1977 ; \mathrm{i}: 90$.

- Dosik H, Hurewitz DJ, Rosner F, Schwartz JM. Bullous eruption and elevated leukocyte alkaline phosphatase in the course of busulfantreated chronic granulocytic leukemia. Blood 1970;35:543-8.

10 Baker $H$. Intermittent high dose oral methotrexate therapy in psoriasis. Brf Dermatol 1970;82:65-9.

11 Davies MG, Holt P. Pemphigus in a patient treated with penicillamine for generalised morphea. Arch Dermatol 1976;112:1308-9.

12 Tan SG, Rowell NR. Pemphigus-like syndrome induced by D-penicillamine. Br F Dermatol 1976;95:99-100.

13 Marsden RA, Ryan TJ, Vanhegan RI, Walsh M, Hill H, Mowat AG. Pemphigus foliaceus induced by penicillamine. $\mathrm{Br}$ Med $\mathcal{F}$ 1976;ii:1423-4.

14 Gange RW, Rhodes EL, Edwards CO, Powell MEA. Pemphigus induced by rifampicin. Brf Dermatol 1976;95:445-8.

15 Thomsen K, Schmidt H. PUVA-induced bullous pemphigoid. $\mathrm{Br} \mathcal{F}$ Dermatol 1976;95:445-8.

16 Van Joost Th, Faber WR, Manuel HR. Drug-induced anogenital cicatricial pemphigoid. BrF Dermatol 1980;102:715-8.

17 Van Joost Th, Crone RA, Overdijk AD. Ocular cicatricial pemphigoid associated with practolol therapy. Br $\mathcal{F}$ Dermatol 1976;94:447-80.

18 Gaylarde PM, Sarkany I. Side effects of practolol. Br Med $\mathcal{F} 1975 ;$ iii:435.

19 Van Joost $\mathrm{Th}$. Incidence of circulating antibodies reactive with basal cells of skin in drug reactions. Acta Derm Venereol (Stockh) 1974;54:183-8.

20 Van Joost $\mathrm{Th}$. Serum antibodies with affinity to the cytoplasm of epidermal basal cells. In: Beutner EH, Chorzelski TP, Bean SF, eds. Immunopathology of the skin. 2nd ed. New York: John Wiley, 1979:473-88.

\section{Audit: aiming high}

Deciding whether you are for or against audit is as meaningless as deciding whether you are for or against research. Just as most doctors will approve of careful, productive research and ignore invalid or irrelevant projects so will they welcome good exercises in audit. Unlike research, however, audit cannot be confined to a small élite. The results are applicable only to particular groups at particular times: neither the results from a neighbouring ward nor your own from last year necessarily reflect your current efforts, and certainly not those of others.

Much of the confusion about what audit is and what it is not was dispelled at a recent well-attended conference organised by the Royal College of Physicians of London. In the opening paper Dr P C Reynell from Bradford argued that its purpose was not to remove the incompetent few but to raise general standards. As such, audit had to be voluntary; to encourage participation it had also to be fun, constructive, and nonthreatening; and ultimately it had to be seen to have improved patient care. He rejected the assertion, often heard, that audit was something most doctors did already. That was not true: while necropsies, case conferences, ward meetings, and mortality analyses were all important, there was more to be achieved by detailed inspection of daily activities. Nor could the inspection of training posts by the various royal colleges be counted as audit: the inspectors had only a limited aim.

Some medical activities were more easily audited than others. Clinical biochemistry, and indeed most laboratory medicine, was relatively clear cut, and that was probably why most laboratories in Britain had been participating in a national quality assurance programme for many years. Even here there had been problems, however, as Professor T P Whitehead of Birmingham explained: at first laboratories had been slow to act to improve their results; and some laboratories had refused to join the scheme. Ascending the scale of complexity, audit was perhaps easier in hospital medicine than in general practice: the "aims" and problems of hospital medicine were clearer; "standards" were more uniform; comparisons could be made more easily with other units; medical records were often much better kept; and, finally, as Professor Michael Drury from Birmingham observed, general practitioners jealously guarded their independence. Within hospital, surgical practice, which often had a definite endpoint, was perhaps easier to audit than medical practice: Professor Ian McColl of Guy's Hospital Medical School was most enthusiastic about audit on a general surgical ward, while Professor Paul Turner of St Bartholomew's Hospital saw considerable difficulties in auditing prescribing. Interestingly, no psychiatrist had been asked to speak, and it needed a lay member of a community health council to ask whether psychiatric practice could be audited. The distinguished panel, none of them psychiatrists, saw no reason why it could not be.

No matter what the context, however, the activities to be audited were much the same. Clinical practice was obviously top of the list, since mistakes resulted usually not from lack of knowledge but more from its disordered application. Administration and organisation were more prime targets, and increasingly cost effectiveness was something that doctors had to consider. Finally, doctors were offering a service, and consumer satisfaction-which was so often a matter of communication between doctor and patient-was important to audit.

Was there, however, any hard evidence that audit actually improved patient care? Dr G H Hall, of Exeter, who with great style played the devil's advocate and argued against audit, quoted some of the depressing American experiences where at huge expense great piles of data had been generated with absolutely no effect. Audit would, he claimed, be expensive, and results might be taken up and abused by zealous antidoctor groups. Other speakers mostly disagreed, arguing that the American experience was irrelevant to Britain. Thus Dr D A Heath, from Birmingham, had audited his audit and compared his results with an unaudited control group. He was able to show considerable improvements in his unit's records but no changes in investigation or treatment. The clear mood of the conference was that audit had arrived and that its intelligent use would raise standards in the 1980s. 